Journal of Latin American Studies

http://journals.cambridge.org/LAS

Additional services for Journal of Latin American Studies:

Email alerts: $\underline{\text { Click here }}$

Subscriptions: $\underline{\text { Click here }}$

Commercial reprints: $\underline{\text { Click here }}$

Terms of use : $\underline{\text { Click here }}$

\title{
'The Revolution of the Ganhadores': Urban Labour, Ethnicity and the African Strike of 1857 in Bahia, Brazil
}

JO\&Atilde;O JOS\&Eacute; REIS

Journal of Latin American Studies / Volume 29 / Issue 02 / May 1997, pp 355 - 393

DOI: 10.1017/S0022216X9700477X, Published online: 08 September 2000

Link to this article: http://journals.cambridge.org/abstract_S0022216X9700477X

How to cite this article:

JOÃO JOSÉ REIS (1997). 'The Revolution of the Ganhadores': Urban Labour, Ethnicity and the African Strike of 1857 in Bahia, Brazil. Journal of Latin American Studies, 29, pp 355-393 doi:10.1017/S0022216X9700477X

Request Permissions : $\underline{\text { Click here }}$ 


\title{
'The Revolution of the Ganbadores': Urban Labour, Ethnicity and the African Strike of 1857 in Bahia, Brazil*
}

\author{
JOÃO JOSÉ REIS
}

Abstract. This article discusses the 1857 African porters' strike in Salvador, Brazil. Mobilisation for this unique movement was organised through work groups, based on ethnic affiliation, within which Africans developed a street culture with its own rules, rituals and symbols, all of which were essential to the creation of the group's identity and to pursue resistance in the urban slavery environment. The movement lasted for a week and it may have been the first of its nature in the history of urban Brazil.

In 1857 the majority of blacks in urban Bahia, both enslaved and free, worked either in the streets, or partly in the home and partly in the streets. They were responsible for the conveyance of goods and people in the "city of Bahia', as Salvador was called (after the province of Bahia, of which it was the capital). Blacks carried everything: large and small packages, from letter-sized envelopes to large sugar crates; casks of water and slops, liquor barrels and people in sedan chairs. When he visited Bahia in 1847 , the French Baron Forth-Rouen had the impression that black men and women made up 'the majority of Bahia's population, and [are] the only ones to be seen in the streets, like beasts employed to carry all kinds of burdens, and which circulate laden with heavy loads'. Neither mulattos nor whites were seen plying that trade. 'Everything that runs, shouts, works, everything that transports and carries is black', observed the German traveller Robert Avé-Lallemant in $1858 .{ }^{1}$ However, at dawn on Monday, I June 1857 , the streets of Salvador were strangely quiet. The black porters had decided to fold their arms in protest against a municipal ordinance that was to come into effect on that date.

João José Reis is Professor of History at the Universidade Federal da Bahia, Brazil.

* Translated from the Portuguese by H. Sabrina Gledhill. This article forms part of a more extensive study, carried out with the support of the CNPq and the Centro de Estudos Afro-Asiáticos, Rio de Janeiro. I would like to thank Judith Allen, who first called my attention to the strike of i 857 ; Richard Graham and two anonymous JLAS reviewers for their comments on a previous version of this article; and Sandra L. Graham, for her efforts to see this work published in English.

1 'Bahia en r 847: deux lettres de M. Forth-Rouen', in Henri Cordier, Mélanges Américains (Paris, i913), p. г16; Robert Avé-Lallemant, Viagem pelas provincias da Babia, Pernambuco, Alagoas e Sergipe (1859) (Belo Horizonte/ São Paulo, 1980), p. 22. 
456 João José Reis

Promulgated three months earlier, the ordinance decreed that the ganhadores (literally, 'earners'), as these street-workers were called, would thenceforward be permitted to 'earn' their livings solely through a permit granted by the City Council. To obtain a permit, or registration, each would have to pay 2,000 réis. At the same time, they were to pay an additional fee of 3,000 réis for a metal plaque engraved with their registration number, which had to be worn about the neck when they were at work. The total cost of the transaction, 5,000 réis, was not an inconsiderable sum. In 1857 it was the equivalent of the price of nearly an arroba ( $\mathrm{s}$ kilos) of meat. In addition, the freed ganbadores (former slaves) were to present 'suitable' guarantors who would take responsibility for their future behaviour.

The law was restricted to male ganhadores; the ganhadeiras, black women who primarily sold a variety of groceries, already paid a tax of 20,000 réis per year to pursue this occupation. The Council edict included among the ganhadores; (I) ganhadores de cesto ou tina, meaning those who individually carried liquids (chiefly water) in casks, and small but solid objects in baskets; (2) ganhadores de pau e corda, who transported larger, heavier cargoes in groups using long sticks and ropes; (3) carregadores de cadeiras, who worked in pairs to carry people. The edict also added that the order would apply to "those others who make "earning" their habitual profession', which included virtually all blacks who worked for pay in the streets. $^{2}$

This law was one of a large number devised by the public authorities to control the work of blacks, particularly those of African birth, in Salvador. In fact, the general aim was to control the circulation of blacks in public places, when at work and at leisure. Slaves or freed, they had to be carefully watched. They were to be watched when plying their professions in the streets, whether as porters or sellers of merchandise and services, and when drumming, practising Capoeira (the Afro-Brazilian martial art/dance) or simply inactive. According to laws which were systematically disobeyed, slaves were to carry passes signed by their masters and freed blacks had to have passports signed by the police, designating when and where they could circulate. Above all, they were not to lurk in the shadows of the night. However, in this article, I will focus on measures to restrain black, particularly African street activities in daylight hours.

The strike of 1857 was an instance of African resistance to such restraints. However, it was not an ordinary event. The ganbadores virtually paralysed transportation in Salvador for over a week, in the course of a

2 Jornal da Babia, I6 March i 857 and 8 May i 857 , from the periodicals collection of the Biblioteca Pública do Estado da Bahia. 
movement that could be considered the first general strike by an important segment of Brazil's urban economy. ${ }^{3}$ In order to understand how that became possible it is necessary to understand the nature of the work of those of African birth in Salvador, and particularly of those Africans who went on strike. The central argument of this article is that the ganhadores mobilised the strike on the basis of labour organisations that preceded the movement and were built up on the basis of the ethnic and cultural characteristics of those Africans. African ethnic identity and cultural practices, had very clear political dimensions, both in their daily occupations and at the times when they broke with those daily routines, as in the case of the strike and the other conflicts that preceded it. These conflicts, principally the cycle of slave rebellions and conspiracies that occurred in Bahia in the first half of the nineteenth century, had already aroused a fear of black autonomy among Bahian slaveowners and authorities alike by the time the strike of i 857 took place.

\section{Street labour and street culture}

The blacks were primarily feared because of their numbers. Estimates of Salvador's population in 1857 vary greatly. Kátia Mattoso proposes 89,260 and Ana Amélia Nascimento 58,498. ${ }^{4}$ Contemporary sources may have exaggerated: the Jornal da Babia, for example, hazarded a 'well calculated' guess that its population was I40,000 to I 50,000. 'Although doubt exists as to the total figure, there is less speculation regarding the fact that whites formed a minority of about 30 per cent. There were probably even fewer, if we consider that the slave population was systematically underestimated by slaveowners, who avoided having their slaves counted because they feared taxation or even the confiscation of those imported illegally after I $831 .{ }^{6}$ It is calculated that just in the fiveyear period that preceded the definitive end of the slave trade in 1850 about 46,000 slaves arrived illegally in Bahia. ${ }^{7}$ Although the majority were

3 Therefore, it came before the printers strike in Rio de Janeiro, which Koval claims to have been 'the first strike in Brazilian history' in January 1858 ; see Boris Koval, História do proletariado brasileiro, I857 a 1967 (São Paulo, I982), pp. 71-2; see also Hermínio Linhares, Contribuição à história das lutas operárias no Brasil, 2nd ed. (São Paulo, I 977), pp. 33-4.

4 Kátia M. de Q. Mattoso, Babia: a Cidade do Salvador e seu marcado no século XIX (São Paulo/Salvador, 1978), p. I38: Ana Amélia V. Nascimento, Dez. freguesias da cidade de Salvador, (Salvador, I986), p. 65. $\quad{ }^{5}$ Jornal da Babia, 9 Feb. I 857.

${ }^{6}$ On the fear of a census, see James Wetherell, Brazil: Stray Notes from Babia (Liverpool, I 860), pp. 95-6; Sub-Commissioner Manoel R. Valença to the Chief of Police, 3 I July I 854, Arquivo Público do Estado da Bahia (Public Archives of the State of Bahia, henceforth APEBa), Polícia, maço 623I.

7 Herbert Klein, 'A demografia do tráfico atlântico de escravos para o Brasil', EstudosEconômicos, vol. I7, no. 2 (1987), p. 133. 
taken to plantations in the Recôncavo, the sugar-growing region near Salvador, or were re-exported to the south of the country, a few thousand must have remained in the capital without figuring in official statistics.

In any case, the slave population was also in the minority in 1857 , accounting for between 30 and 40 per cent of the total population. However, when added together, slaves, freedmen and freeborn people of African descent formed the vast majority. The blacks alone made up about 40 per cent of the population, and at least half were born in Africa. As we have seen and will see in greater detail further on, it was they who lent colour to the life of the streets of Bahia. 'Opulent city of the blacks' was Avé-Lallemant's final impression of Salvador, after having visited Pernambuco, Alagoas and Sergipe as well. ${ }^{8}$ Attempts to control blacks dated back to colonial times and intensified after Independence, primarily in the wake of the slave rebellions that terrified slaveowners during the second half of the nineteenth century. Those uprisings were organised by those of African birth. The feared blacks were those born in Africa, who made up the majority of the slaves in Bahia.

In Salvador, a major port for the Atlantic slave trade, the majority of the enslaved population was also born in Africa, and the tendency for slaves to be 'nationalised' only began when the slave trade ended in i 850 . According to data furnished by historian Maria José Andrade, between the beginning of the century and i 849,67 per cent of the slave workforce consisted of Africans. In the 185 os, that proportion fell to 53 per cent. In another work, I have calculated that Africans (enslaved and freed) made up about 33 per cent of Salvador's total population in i 835 . According to Nascimento's estimates, that proportion was to fall to nearly 24 per cent two decades later. ${ }^{9}$

Other characteristics of African demographics should be recalled, because they will aid in the understanding of the 1857 strike. Between I 750 and I 850 , Bahia imported the majority of its slaves from the Bight of Benin region and the former Dahomey, primarily the Aja-Fon, Yoruba and Hausa peoples, known respectively in nineteenth-century Bahia as Jejes, Nagôs and Ussás (or Haussás). ${ }^{10}$ During the nineteenth century, those of the Yoruba 'nation', or Nagôs, came to form a formidable majority. I will focus on the men (who made up 60 per cent of the African community), because it was they who organised the strike in I 857 . Since

8 Avé-Lallemant, Viagens, p. 272. On the proportion of whites, slaves, etc., see Nascimento, Dez feguesias, p. 97; João José Reis, Slave Rebellion in Brazil: The Muslim Uprising of 1835 in Babia (Baltimore and London, 1993), p. 6.

9 Maria José Andrade, A mão-de-obra escrava em Salvador, I 81 I-I888 (São Paulo, I988), pp. I 89-90; Reis, Slave Rebellion, p. 6; Nascimento, Dez freguesias, p. 95.

10 In this article I will employ the ethnic terminology used for and by Africans in nineteenth-century Bahia, except when referring to their origins in Africa. 
the general census of 1855 does not contain the detailed information this study requires, I will provide a closer look at them through a registration count, or survey, carried out in I 849 in Santana, an urban parish typical of Salvador. This survey counted 925 slaves, 55 I (60 per cent) of whom were from Africa. Many of the latter were of unspecified nationality and listed merely as 'Africans'. However 78 per cent of the 475 whose nationality was given were classified as Nagô. This confirms the findings of studies that demonstrate that Yorubas formed the majority of the slaves brought from overseas in the latter years of the slave trade. They also predominated among former slaves: 70 per cent of the 87 freed Africans of known origin cited in the 1849 list were Nagô. ${ }^{11}$

Disciplining African workers was a thankless task, particularly in the city. The slaves needed to be independent and free to move about in order to do their work, and so be profitable for their masters and sustain the local economy. The ganhadores moved about freely in the streets looking for work. It was a common, although not general, practice for slaveowners to permit their slaves to live outside the master's home in rented rooms, sometimes with former slaves as their landlords. They only returned to the master's house to 'pay for the week', that is, to pay the weekly (and sometimes daily) sum agreed upon with their masters. They were able to keep whatever exceeded that amount. Slaves who worked hard in favourable market conditions managed to save enough to purchase their freedom after years of toil. Freed slaves frequently plied the same trades they had when in captivity, although some prospered to such an extent that they themselves became the masters of enslaved ganbadores. The fact that slaves and freedmen worked side by side gave a sense of liberty to the former, and also a sense of enslavement to the latter, a situation which created a constant short-circuit in relations between urban ganhadores and the free population. Occasionally this flared up in the form of individual rebellion-an escape or conflict with the slaveowners, other free individuals and government officials - or as collective uprisings.

These were the general characteristics of urban slavery, wherever it flourished, although slaves put their own stamp on history in every city. In Bahia, for example, there were many attempts to spark a rebellion (and not just in the city). One of the strongest reasons for this can be found in the ethnic concentration of the ganhadores.

Among the Nagôs of Santana, many slaves plied trades. There were cobblers, tailors, bricklayers, bakers, caulkers, barbers and carpenters.

11 'Relação de Africanos residentes na Freguesia de Santana etc. (i I Feb. i 849)', APEBa, Escravos (assuntos), maço 2898; on the slave trade in the Bight of Benin, see Pierre Verger, Flux et reflux de la traite des nègres entre le Golfe de Bénin et Babia de Todos os Santos (Paris, I968). 
However, 30 per cent of the Nagô slaves worked exclusively in the streets, the majority as bearers of cargoes and people, aboard saveiros (the forebearers of the Bahia schooner), on their backs or in sedan chairs. Forty per cent were registered as 'house servants', but this should not lead us to believe that these men worked exclusively as domestics. Because household slaves were not taxed, it is possible that many of them were so registered by masters who feared that they would be penalised if their slaves were known to be hired out. I agree with Mattoso when she writes that "the difference between "hired-out" ... and domestic slaves was tenuous, because slaveowners used them or rented them according to the needs of the moment' ${ }^{12}$ With a small margin for error, it can be said that the majority of African slaves in Salvador worked as ganhadores either part or full-time. Thus, in 1857 the authorities had a movement on their hands that involved the majority of the city's slaves. In addition, perhaps chiefly, it involved freed blacks.

None of the 87 freedmen registered in Santana is listed as a domestic. Eighteen of the 6r Nagôs declared that they were sedan-chair bearers; seven were rowers, five were cangueiros (bearers who carried their loads on poles), and ten were generically categorised as 'ganhadores'. In other words, nearly 65 per cent worked in the field of transport. The others were either tradesmen or artisans. In contrast, just one of the is Jejes, members of the second-largest ethnic group among the freed slaves, declared that he was a ganbador, and none was a sedan-chair bearer or the like. Nine were artisans. Whether enslaved or free, the Nagôs virtually dominated the 'informal' street labour market in I 849 and, as we shall see, this was also true in 1857 . They were chiefly responsible for the strike.

This concentration of Africans of the same origin, together with the nature of urban slavery - slavery without overseers, as has been observed elsewhere ${ }^{13}$ - led to the development of a more independent and intrepid slave culture. In turn, their African ethnic identities and their cultural density aided the slaves' resistance to their masters, to the police and to the free population in general. Despite the watchful presence of the police, religious congregations, work and recreational groups, smaller or broader networks of solidarity and companionship based on ethnic identity were more easily formed amidst the bustle of the port city, not that they were lacking on the sugar plantations. Although one African people outnumbered the rest, all African peoples participated in mutual cultural exchange, negotiation of identity and re-definition of solidarity.

12 Kátia M. de Q. Mattoso, Babia século XIX: uma provincia no Império (Rio de Janeiro, I992), p. 538. By the same author, on primarily urban slavery: Être esclave au Brésil (Paris, I 979), passim.

13 Leila M. Algranti, O feitor ausente: estudos sobre a escravidão urbana no Rio de Janeiro (Petrópolis, 1988). 
The Nagôs, for example, came from a Yoruba region divided into subgroups that were frequently hostile towards each other, and divided by religious affiliations and political loyalties. The Yoruba of the Oyo, Egba, Ijebu, Ilesha and Ketu kingdoms became Nagôs in Bahia through complex exchanges and convergences of cultural signs with the help of a common language, similar divinities (Orishas), the unification of many under Islam, long experience as subjects of the Oyo alafins (kings), Yoruba urban traditions and, obviously a life of slavery in Bahia. The memory of their specific origins would never be completely expunged among these Africans. 'Although all are Nagô, each has his own homeland', is the attempted explanation given by a Nagô slave to the police who interrogated him after the uprising of $1835 .{ }^{14}$ There were other divisions as well, such as that between the children of Allah and the children of the Orishas, and between both and the followers of Catholicism. However, the Africans' pliant, flexible, absorbent religious spirit enabled many to move in various religious circles. Competition and even conflict did exist. However, Muslim groups, Candomblé temples and Catholic lay brotherhoods acted primarily as areas of congregation. It was through these groups that slaves perfected their daily strategies of resistance, and decided to break with their day-to-day oppression. Thus it was in I 835 when Muslim slaves and freedmen, known as Malês (the majority Yoruba) rose up in Salvador during the most dramatic urban slave rebellion in Brazilian history. ${ }^{15}$

The strength of the slave culture of nineteenth-century Bahia must be understood in light of the slaves' working experience. This is not a matter of deducing culture from labour procedures and relations - a conservative-functionalist or orthodox Marxist operation - but of considering that slaves did not cease to produce cultural signifiers when producing merchandise or providing services. Only if they had permitted an absurd objectification of themselves would it have been otherwise - only if the 'master time', that is, work time, had become an absolutely mechanical interval in their lives, a time without any significance for the slave; as though only 'the slaves' time', their time of rest and recreation, their Sundays, were the only period in which they expressed their 'true' culture. Peter Kolchin has pointed out the failings of this perspective in his research on the American slave community. He convincingly writes: 'Often this position leads scholars to play down the socio-economic setting of slavery and, indeed, the work experience of the slaves, as if the slave community somehow flourished outside the institution of slavery. ${ }^{, 16}$ However, if the slave culture was irremediably linked to the slave labour

14 Cited in Reis, Slave Rebellion, p. I54. ${ }^{15}$ Ibid., passim.

16 Peter Kolchin, 'Reevaluating the Antebellum Slave Community: A Comparative Perspective', The Journal of American History, vol. 70, no. 3 (1983), p. 58 I. 
system, the latter was also an integral part of a developing cultural system in which slaves played a fundamental role.

In urban slavery, both the master's and the slave's time was invested in labour, although not in a 'secret' manner, as in capitalist production. The slave had to provide for the master and him or herself directly through earnings in the streets, and knew exactly what belonged to him or herself and to his or her owner. The slave's chances of purchasing freedom depended directly on how much he or she earned. However, each day's work was discontinuous and patchy, in part because of the intervals between one job and another. Furthermore, there was no means of preventing a slave from setting aside his basket, rod or rope to join in or watch Capoeira, dance samba in the round, seek out a shaman in the outskirts of the city or disappear into a house to pray to Allah the Merciful. The slave, together with the freedman, regularly and daily contrasted his or her moral economy of labour with that of the master. This took place even in small towns in the Recôncavo, such as the outskirts of Nazaré das Farinhas where, according to a police report dated I 845, a Nagô slave who claimed to be a prince in his homeland was accused of gathering other captives 'on workdays... and there erupt drumming, shouts, disorder and other things ... ${ }^{17}$ In larger cities, slaves forged the 'city hideaway' as Sidney Chalhoub aptly defines nineteenthcentury Rio de Janeiro, where the slave could prevent his master from knowing where he lived and even how he made a living. ${ }^{18}$ The slave often earned money from several clandestine sources, such as drumming, Capoeira and divination. A not insignificant number of slaves earned their living telling fortunes, curing spells or making Muslim amulets, which were profitable occupations that enabled many to purchase their freedom. In I85I, James Wetherell observed that the blacks of Bahia often performed samba in the round in exchange for a few coppers. These were alternatives to conventional outdoor labour. ${ }^{19}$

The wage-earning slave organised his own work time - the time, pace and even amount of his labour. The ganhador's work was paid for by task (and not according to units of time), a familiar system for Africans. Among the Yoruba people, according to Afolabi Ojo, in certain circumstances time itself was distinguished by the amount of work. In nineteenth-century Bahia, a limit could be set to that amount if the slave was able to set such limits, as in the case of the ganhadores. Wetherell observed this labour-saving effort among the African porters: 'They are

17 Apud João J. Reis, 'Recôncavo rebelde: revoltas escravas nos engenhos baianos', Afro-Ásia, vol. is (1992), p. i 25.

18 Sidney Chalhoub, Visões da liberdade: uma bistória das últimas décadas da escravidão na Corte (São Paulo, 1990), pp. 21 2ff. $\quad{ }^{19}$ Wetherell, Bražil, p. 56. 
extremely independent, they would rather lose the chance of gaining a wage than carry more than they thought proper.' This was something rather different from the linear time and mechanical pace of capitalist consumption of labour. In regard to this traditional African temporal sense, anthropologist Benjamin Ray notes, "Time is episodic and discontinuous; it is not a kind of "thing" or commodity'. It is similar to the 'kefir time' of the South African workers studied by Keletso Atkins. Whether under the colonial regime in their homelands or under slavery on foreign soil, for as long as they could, Africans resisted the overthrow of their concept of time and labour. ${ }^{20}$

The porters' work was characterised by a unique rhythm observed by virtually all foreign visitors. The 'ganhadores de pau e corda', for example, worked to the rhythm of songs sung in African languages when carrying heavy loads in groups of four, six or eight. Prince Alexander of Wuerttemberg, who spent the month of April 1853 in Bahia, wrote, 'Whether going down or up the hills, scaling steep slopes and rocky paths - they sing! They always sing when on the march.' In accordance with African rhythmic traditions, a call-and-response singing style was employed. According to Wetherell, when the burden was particularly heavy, or when they were going uphill, the Africans 'would become much more vigorous in their shouts, aiding their labour and varying their song with an expressive long grunt'. It was hard, exhausting work, 'work for blacks', as the saying went, because whites would not do it, and even Brazilian blacks, or Crioulos, appeared reluctant. In the 1849 survey undertaken in Santana, there were nearly 240 Brazilian-born adult slaves. None was listed as a sedan bearer and only i I were ganbadores, possibly 'ganhadores de cesto e tina'. There was not one ganbador among the 43 mestizos (mulattos and cabras). ${ }^{21}$

The music that enlivened those black bodies might have helped ease the weight on their shoulders, but above all it eased the spirit, enabling Africans to persevere, assert their humanity and avoid despair. It helped ensure a certain 'framework for community integrity', as John Chernoff

20 G. J. Folabi Ojo, Yoruba Culture (London, I966), p. 203; Wetherell, Brazil, p. 54 (original emphasis); Benjamin C. Ray, African Religion: Symbol, Ritual and Community, (Englewood Cliffs, I976), p. 4I; Keletso Atkins, "“Kefir Time”: Preindustrial Temporal Concepts and Labour in Nineteenth-Century Colonial Natal', Journal of African History, no. 29 (1 988), pp. 229-55 and Frederick Cooper, 'Colonizing Time: Work Rhythms and Labor Conflict in Colonial Mombasa', in N. Dirckes (ed.), Colonialism and Culture (Ann Arbor, I992), pp. 209-45. For a comparison with Europe, see the classic work by E. P. Thompson, 'Time, Work Discipline and Industrial Capitalism', Past \& Present, vol. 38 (1967), pp. 56-97.

21 Paulo Alexandre de Wuerttemberg, 'Viagem do príncipe P. A. de Wuerttemberg à América do Sul', Revista do Instituto Histórico e Geográfico do Brasil, i71 (1936), p. 9; Wetherell, Brazil, pp. 53-4. 
464 João José Reis

writes in a sociological study of African music. Viewing it as an expression of joy or acquiescence is a superficial view, held by foreign travellers such as Alexander Marjoribanks of the United Kingdom and W. Detmer of Germany. Another visitor, the Reverend Daniel Kidder, compared it with a funeral march with exaggerated Christian piety. Reflecting on the need for improvisation during the work they did in the streets, the ganbador improvised his own work tunes, 'chanting a remark on anything he sees', according to Wetherell. It is not surprising, therefore, that in addition to traditional African work songs, the ganbadores invented lyrics critical of slavery and scornful of whites. Prince Maximilian of Austria (later shot as Emperor of Mexico) was informed during a visit to Salvador in i 860 that slaves mainly sang about manioc flour and cachaça (the local rum), adding, 'They occasionally allude to relations between master and slave and the manner in which they are treated'. Because manioc flour was a staple of the local diet, speaking of it was a reference to food in general. In a slave song it was a reference to hunger, bad food, or even a monotonous diet, and the desire for a well-laden table set with a variety of dishes. Cachaça, above all, meant the penetration of the Dionysian strain of African culture into the breach of slave labour. If they sang constantly about manioc flour and cachaça, Bahia slaves spoke constantly of slave relations and not merely 'occasionally' as Maximilian suggested. Naturally, the ganbadores' songs also alluded more directly to the exploitation of labour and other burdens of slavery. Folklorist Silva Campos recalls that they sang the following tune when carrying heavy loads:

$\begin{array}{ll}\hat{E} \text {, cuê... } & \hat{E}, \text { cuê... } \\ \text { Ganhadô } & \text { Ganhadô } \\ \text { Ganha dinheiro } & \text { Earns money } \\ \text { Pra seu Sinhô } & \text { Fo' his Massa }\end{array}$

Was this naïve submission? It might have seemed so to the 'Massa', but the ganhador was telling everyone who could hear him that the fruits of his labours were being snatched from him. And he over-emphasised that exploitation when he concealed the fact that part of his earnings went to him, as was common in urban slavery. Slavery was denounced while singing. A basic cultural element of the African way of being, music accompanied everything that was most (or even least) important in a slave's life, in joy and in pain. And no matter how oppressive it may have been, work was not disconnected from life. ${ }^{22}$

22 John M. Chernoff, African Rhythm and Sensibility: Aesthetics and Social Action in African Musical Idioms (Chicago, 1979), p. 26; Daniel P. Kidder, Sketches of Residence and Travels in Brazil etc., vol. 2 (Philadelphia \& London, I845), p. 25 ; Marjoribanks and Detmer apud Moema Augel, Visitantes estrangeiros na Babia oitocentista (São Paulo and Brasilia, 
Although urban slave labour provided opportunities and even promoted personal initiative, permitting, for example, the escape hatch of purchasing freedom, its organisation was essentially collective. The work itself, as well as its remuneration, were viewed as the result of collective production. Wetherell compared the ganbadores of Bahia with British stevedores, concluding that, if they carried extremely heavy loads together, the Britons carried more weight individually, encouraged by their wages. ${ }^{23}$ By contrast, the Africans would not do all kinds of work for money. Individual labour of the worker-boss kind was not a strong cultural value among them. An episode described by the director of the public cemetery of Bom Jesus da Massaranduba in Salvador in I 856 is illustrative here. According to him, three 'free Africans' worked there, two of whom, for some reason, had been transferred elsewhere by the district deputy marshal, the sub-delegado ${ }^{24} \mathrm{~W}$ ith reference to the one who remained, he wrote:

the black refuses to do the same work because he is unhappy at being deprived of the company of his fellows and because work greater than his strength has fallen to him, so that on the 24 th he fled to the home of the said sub-delegado. ${ }^{25}$

That man had not run away from slavery but rather from solitude. It never occurred to him to ask to be paid more to compensate for his increased labour. In addition to having more work to do, which he claimed to be unable to handle, perhaps he did not want to be alone in the presence of the dead, especially dead people who were not of his kind. From every angle, this incident suggests the gregarious personality of the African at work. The outcome of the story was that the president of the province ordered that the number of gravediggers be increased to three.

That spirit of belonging to a group or a community partly explains the labour organisation created by the Africans of Salvador. The ganhadores were ethnically organised in cantos, as their work groups were known. ${ }^{26}$ They gathered to offer their services in areas that were carved out of the urban geography. Even a basket porter, who floated in the labour market on his own, found his collective anchor in the canto. The inspiration for this type of organisation may have been the volunteer work groups

I980), p. 217; Wetherell, Brazil, p. 53; Maximiliano apud Verger, Notícias da Babia (Salvador, I981), p. 217 ; João da Silva Campos, 'Ligeiras notas sobre a vida íntima: costumes e religião dos africanos na Bahia', Anais do APEBa 29 (1943), p. 294.

23 Wetherell, Brazil, pp. 53-4.

24 A free African (africano livre) was one confiscated from smugglers after the slave trade was prohibited in $183 \mathrm{I}$, and frequently employed in public services in exchange for a small wage. $\quad 25$ APEBa, Saúde. Falecimentos, maço 5500. 'Free Africans'.

26 Translator's note: the word canto means both 'corner' and 'song' in Portuguese, and the author bears that double meaning in mind throughout this article. 
commonly found in Western Africa, known as aro among the Yoruba. ${ }^{27}$ The Bahia cantos took the names of streets, plazas, hills and wharves: canto da Calçada, do Portão de São Bento, da Mangueira, do caes Dourado. 'Canto' means song in Portuguese, and thus the canto could be etymologically connected to work songs. However, the term entered Bahia's urban history as a street corner, a strategic place in street culture in general because it was a place of transit, convergence and gathering. In the African world view, cross-roads have matchless mystical importance: they are a place for offerings, for negotiating with the gods, the place of Eshú, the opener of ways, the Yoruba trickster and divine intermediary. When working for pay, the street corner facilitated the trade because it made it easier to reach customers coming from different directions, as well as being an easy point of reference. However, if a street corner was ideal, the canto could be anywhere - a square, a hill, a wharf - where it was easiest for ganhadores to find customers. 'As the activity of the blacks of the cantos chiefly involved carrying people and merchandise, that is, transportation, ... their location within the physical structure of the city follows the logic of the articulation, mobility and function of the city', writes architect Ana da Costa. ${ }^{28}$

For the ganhador, the important territorial aspect of the canto reinforced deeper feelings of belonging. Many means and ways of life were found there. In addition to the porters who came and went, African artisans were also found there mending shoes and umbrellas, weaving baskets, hats and sleeping mats, making necklaces and bracelets with beads - older porters who had turned to less tasking occupations. There were barbers, who for ritual reasons and magical protection were not allowed to leave their customers' hair lying about, disposing of it in a 'convenient' place. They also used their sharp razors to perform phlebotomies - the art of bleeding to cure disease - or practised musical instruments to play in the famous barber bands of that time. Some ganbadores rested there to regain their strength: As Daniel Kidder observed in the late i830s, 'The sleepers generally have some sentinel ready to call them when they are wanted for services.${ }^{29}$ While they were awaiting customers, followers of Candomblé carved images of their divinities and Muslims stitched Malê robes and caps, learned to read and write in the language of the Koran from their teachers, and recited the prayers of their faith. Africans who belonged to lay Catholic brotherhoods certainly frequented such places as well, and

27 Robin Law, The Ovo Empire, c. I600-c. 1836: A West African Imperialism in the Era of the Atlantic Slave Trade, (Oxford, 1977), p. 203.

28 Ana de Lourdes R. da Costa, "Espaços negros: "cantos" e "lojas" em Salvador no século XIX', Cantos e Toques. Supplemento do Caderno CRH (Salvador, I99I), p. 25.

29 Kidder, Sketches, vol. 2, pp. 20-I. 
probably discussed the business of those institutions - which were equally as ethnically oriented as the cantos - discussing their processions, masses, funerals, festivals, the recruitment of new members, or the concert in the chapel. The canto was also a place where African women gathered to sell mingan (a kind of gruel made from tapioca, cornmeal and other products), aberém (a cake made of grated corn steamed in a banana leaf), caruru (okra stew), vatapá (a savoury yellow paste made of flour, cashews, peanuts, palm oil and dried shrimp) and other African delicacies. While in the canto, men and women also discussed local events and news of their homelands, which arrived aboard ships from Africa. The canto was, therefore, much more than a place of work. ${ }^{30}$

As symbols of the Africans' occupation of public space, the areas where they set up their cantos frequently became the source of disputes. An example of this occurred in I 859 between the ganhadores of the Galinheiros alley canto, on a street corner in the Comércio port district, and shopowner Francisco José de Farias Villaça. On the same corner, Villaça operated a 'dry goods store' whose trade he alleged was harmed by the bustling life of the canto. According to the complaint made to the City Council authorities. Africans were

so numerous that not only do they virtually block passage through that alley but also produce such a horrible commotion and proffer such obscenities that they disturb the Merchants, who cannot carry out their serious occupations.

Villaça also complained that he was the victim of constant theft; the reason why the door of his shop that opened onto the alley was kept shut. He suggested that the noisy ganhadores be transferred to a more spacious location, suggesting Taboão Hill, where a canto of sedan bearers already existed. His request was denied. The Council officer found that the canto had already occupied that alley for a long time and had acquired legal rights due to longevity, being 'tolerated by all Councils in consequence of their (the ganhadores) being necessary for the operations of commerce'. Evidently that commerce was much more important than the trade of the merchant Villaça. As for the transfer he suggested, the officer decided that Taboão was a heavily travelled area that was already occupied by the sedan bearers. In sum, the ganbadores won the dispute over space. ${ }^{31}$

Villaça accused the ganhadores of theft. It is true that news articles were frequently published in the newspapers denouncing them for having purloined the merchandise they were entrusted to carry. The Portuguese

30 Cantos: ibid., pp. 21-7; Manoel Querino, A raça africana e seus constumes (Salvador, I 955), pp. 87-8; Silva Camps, 'Vida íntima', pp. 291-4; Verger, Flux et reflux, 524-7; Nina Rodrigues, Os africanos no Brasil, 4th ed. (São Paulo, I976), pp. Io I-2.

31 Arquivo Municipal de Salvador (AMS hereafter), Câmara. Requerimentos, I860, not catalogued (n/c hereafter). 
ship's captain José Francisco Alves landed in Salvador and 'delivered to a hired black a small parcel of clothing and papers... said black having disappeared...', according to an announcement published in Correio Mercantil on 5 May i 838. Naturally, by wearing the white man's clothes, the black man in question could have cut an excellent figure before his fellows. However, it is more probable that he sold it to another white. Money was in short supply at that time, a few days after the re-conquest of a squalid Salvador by legalist troops from the hands of Federalist rebels after months of siege. The ganbador did not do such things every day, and probably the majority never did so. However, accusations such as Villaça's and cases such as Alves's, which were announced in the press, linked the ganhadores' labour with crime - as is frequently the case with informal labour. The image certainly did not reflect the predominant values of the canto, which had to follow strict standards of honesty in regard to their clientèle in order to survive and prosper.

In order to establish and enforce such standards, the cantos possessed their own power structure. If Villaça had been more diplomatic, he might have negotiated a truce with the leader of the Africans at Galinheiros alley. The cantos were not the chaotic gatherings he had attempted to portray. Their leaders were called capitães-do-canto or canto captains, whose function included hiring out services to customers, assigning tasks, receiving and sharing payment, mediating conflicts that might arise among the ganhadores and negotiating with characters such as Villaça. They may also have been 'puxadores' de canto (leaders of call-and-response singing), in the musical sense. Naturally, the capitão would have expected to receive additional payment. Unfortunately we lack information on how he was chosen, but it was probably based on the length of time he had spent in Bahia and his knowledge of the whites' language and customs, which translated as experience in the labour market. Of course, charisma and leadership ability were also required. That leadership may also have reflected a political or religious hierarchy brought from Africa and re-established in Bahia. The Nagô Orisha priest Elesbão, a character in a nineteenthcentury novel by Xavier Marques, was a capitão-do-canto, and as such had managed to 'build up his savings and purchase his letter of manumission'. In Bahia, both freedmen and slaves could be canto leaders - just as they could be Orisha priests and Muslim teachers-demonstrating that hierarchies within the African community did not always reflect those of the slaveocratic society. Thus, the inquest on the rebellion of 1835 mentions a slave captain who led enslaved and freed African sedan bearers gathered at the canto of Vitória, then a wealthy district of Salvador. ${ }^{32}$

32 Xavier Marques, O feiticeiro (São Paulo/Brasilia, 1973), p. 33; 'Devassa do levante de escravos ocorrido em Salvador em i835', Anais do APEBa, 50 (1992), p. 74. 
The original model for such leadership is unknown, but it may be related to a variety of African traditions. We can recall the parakoyi, functionaries of the Yoruba king of Egba who organised and regulated the periodic fairs. There were also the bale, who directed groups of artisans in Yoruba towns. In the history of Dahomey (now the Republic of Benin), the land of the Jejes (Fon), the title 'Captain of the Market' also existed, an official with functions similar to those of the Egba parakoyi. Similarly, the capitão-do-canto could have been inspired by the military title of captain if we consider that the Bahia Africans came from militarised societies in which, during the first half of the nineteenth century, numerous armed groups existed, led by small chieftains such as the Yoruba olorogun. The kingdom of Whydah, on the neighbouring coast of Dahomey, was under the military command of a 'Captain of War'. Many of those in bondage in Bahia had been warriors in Africa, such as the majority of the $2 \mathrm{I}$ slaves interviewed by Francis de Castelnau in the late 1840 s. $^{33}$

It should be noted that when I refer to the parakoyi, bale, olorogun and Dahomey captains, I am not attempting to force an interpretation of African 'survivals' in Bahia. Rather, I am exploring possible organisational models which the Africans might have used to create strategies and structures for survival and resistance under slavery. It is inconceivable that organisations such as the cantos were mere African transplants in the New World. In a way, as Robert Slenes suggests, the Africans 'discovered' a new Africa in Brazil. ${ }^{34}$

The inauguration ceremony for the capitão-do-canto, as described by Manuel Querino, is a good example of the ritualised legitimisation of African leaders within the working environment. The canto members would fill a barrel with sea water and carry it with the help of a rod and ropes in the same way that they carried heavy loads every day. The new leader was mounted imposingly on the barrel, carrying a bottle of liquor (cachaça) in one hand and the branches of a tree in the other, probably leaves with specific ritual/symbolic meaning. Singing as the ganhadores sang while they worked, the cortège described by Querino made its way through the streets of the Lower City, the docks, and returned to its canto, where the Africans were welcomed by members of other cantos of the city. There, the leader would spill some cachaça on the ground. During that part of the ceremony, an area was demarcated within whose boundaries the

33 T. G. O. Gbadanosi, The Growth of Islam among the Yoruba, I84I-1908 (Atlantic Highlands, 1978), p. 2; Peter Lloyd, 'Craft Organization in Yoruba Towns', Africa, vol. 23, no. I (1953), p. 34; Robin Law, The Slave Coast of West Africa, I550-1750, (Oxford, I99I), pp. 5 I, I00; Francis de Castelnau, Reseignments sur l'Afrique Centrale... d'après le rapport des Nègres du Sudan esclaves à Babia (Paris, I 85 I).

34 Robert W. Slenes, “Malungu ngoma vem!”: África encoberta e descoberta no Brasil”, Revista USP, no. I 2 (1991-2), pp. 48-7. 
new leader would have power recognised and legitimised by the leaders of other cantos. ${ }^{35}$

The barrel of salt water may well have symbolised the Atlantic, which the Africans crossed en route to their exile in Bahia. The ocean had enormous significance for these people, because it had split their lives apart, signalling their transformation from Africans into slaves. The tragedy of the crossing represented a painful rite of passage that profoundly changed its victims. Slaves who made the journey on the same ship became the malungos of one another, a kind of symbolic kinship that united them with powerful bonds of affection and solidarity. Having left their blood relatives behind in Africa, in the middle of the ocean a new, fictitious family emerged. This had the blessing of the African gods, including water divinities, who accompanied their followers to the other side of the Atlantic. Spilling cachaça on the ground as the captain did is a characteristic gesture of reverence to the African divinities. In such a manner, the canto workers appear to have wished to represent the break with their native land and at the same time a ritual return to their roots. A rite of passage (in this case the investiture of power), this ceremony, like any rite of passage and power, reasserted the group's solidarity. As George De Vos has observed: 'It is particularly in rites of passage that one finds highly emotional symbolic reinforcement of ethnic patterns. ${ }^{36}$

It was not just the labour market that was enmeshed in ethnic significations. The network extended to the mechanisms of the food market, where competition existed with native-born Brazilians - free whites and mestizos. The ganbadores who sold farm produce sometimes enjoyed surprising advantages because they belonged to a kind of African commercial league. Such networks extended from the fields and farmers' markets of the Recôncavo to Salvador, and enraged their competitors. In I 858, for example, 76 merchants from the town of Nazaré das Farinhas signed a petition to the Provincial Assembly in which they made the following accusation:

it is extremely shocking to observe savage freed Africans and even some slaves carrying out purchases and transactions, and, taking advantage of the convenience of the transporters of these goods being their peers [sic], enjoy preference of purchase, even receiving a lower price, in detriment to the Farmers, thus denying the native-born population, always the most assured [of its rights] in all Countries, that advantageous, honest and lucrative livelihood, which is the coastal shipping trade.

According to these immoderate citizens of Bahia, that trade was

35 Querino, Raça africana, pp. 88-9.

36 About the malungu, see Slenes, "“Malunga ngoma vem!", "pp. $5 \mathrm{I}-4$. De Vos is cited by Charles F. Keyes, 'The Dialectics of Ethnic Change', in C. F. Keyes (ed.) Ethnic Change (Seattle, i981), p. 9. 
allegedly 'entirely given up to African dominance...'. These were possibly Africans from the same ethnic group, 'their peers'. The merchants described how the Africans acted during the weekly fairs:

[T] his flood of social parasites appears in the market, overwhelms the caravans, takes goods from the hands of others by force, imposes on the porters, their peers, the duty of preference and, still not content, as soon as they disembark in this City, and then at a time when goods are scarce, take to the streets, two or three leagues distant, and there make their purchases, leaving even internal consumers deprived of them, and obliged to purchase them from these arrogant and impromptu middlemen at a high price $!^{37}$

It is not plausible that these Africans used brute force as a means of trade, as that would have required much more power than they actually had. Nor did they need to do so, because both men and womenprimarily the Yorubas, Fon and Hausas - had brought from their native lands a formidable background in the art of negotiating. Women were particularly notable for their haggling abilities in Africa, and the wives of the Yoruba kings were also characterised by this love of bartering. ${ }^{38}$ In Bahia, a foreign land, the supposedly savage African middlemen succeeded in forming an intelligent alliance with other African suppliers, leaving the Nazaré merchants high and dry. The latter reacted with the language of ethnic hatred, seeking the protection of the Government rather than plunging into the fray of free trade. They proposed that the Government forbid the Africans from trading, obliging them to work exclusively in agriculture, or impose the unbearable tax of 300,000 réis per year. They were unconvincing, however, because behind the Africans (when they were slaves) were frequently slave-owners who were either represented by, or formed, the Government itself.

The other end of the African network reached as far as Salvador, where street vendors and stall owners were generally women. According to the Santana census of I 849, among the freedwomen who engaged in trade, the majority stated that they 'traded in diverse goods'. Those who were more specific mentioned mingau, acaçá, aberem, fruit, vegetables, beans, rice, corn, bread and fish. These women virtually monopolised this small market niche, according to statements from witnesses dating back at least to Luís dos Santos Vilhena at the turn of the eighteenth century, and confirmed by a number of foreign visitors to Bahia in the following century. In I 835 , after the Malê revolt, a group of Salvador justices of the peace suggested that Africans be forbidden from selling food. The chief

37 APEBa, Abaixo-assinados, I856, março 984. For comparison's sake, see the competition in the food market between slaves and freemen in the British Caribbean in Michael Mullin, Africa in America: Slave Acculturation and Resistance in the American South and the British Caribbean, $1736-1831$. (Urbana and Chicago, 1992), p. I 55.

38 Law, The Ovo Empire, ch. Iо. 
of police himself, a fierce enemy of the Africans, disagreed, arguing that such a prohibition would result in 'sudden scarcity' and confusion when enforcing the measure. ${ }^{39}$

Men sold water, firewood, lime, china, cloth, shoes. They were less active in the sale of food in the streets, but occupied strategic positions in the sale of manioc flour, for example. In 1855 and again in 1857 , the merchants of Salvador accused the blacks - and in some cases the African slaves of Portuguese tradesmen - of monopolising the manioc flour trade. The Africans, allied with the Portuguese, 'Purchase the cargo wholesale as soon as the boats arrive, and having stored it in the Granary, they set its price.' The government only permitted the sale of manioc flour at the Public Granary, a public market where the African buyers made their purchases from sellers who were also African. One petition denouncing this system reads: 'no matter how many buyers appear there ... almost all are Africans and slaves as well, and seek out none but their like, and the undersigned are thereby restricted from competing in the sale of flour with great harm to their interests'. Solidarity similar to that found in the cantos united Africans involved in the sale of products such as manioc flour. ${ }^{40}$

Considering the African's subordinate position in the life of the city, such relationships forged in the marketplace and the streets constituted power relationships; forms of black politics and resistance on a day-to-day basis. The enslaved and freed ganbadores played an important part in the African revolt of I835. Nearly 5 I per cent of the African prisoners indicted during that year were street workers, principally sedan bearers, porters and vendors. Another 17 per cent were artisans, most of whom probably plied their trades within the cantos. They also stood out as the central agents of the conspiracy. ${ }^{41}$

Government officials perceived that they had to exert more control over the ganbadores. The measure that led to the i 857 strike was one such attempt, but other steps had been taken previously.

\section{Control and resistance in the streets}

The weapons fired in I 835 were still smoking when the Bahia government decreed the end of the cantos' independence. In June of that year, the Provincial Legislature authorised Law I4, which was designed to regulate

39 Luís dos Santos Vilhena, A Babia no século XVIII, vol. I (Salvador, I969), pp. 93, I 27, I 29-30; Augel, Visitantes, passim; Reis, Slave Rebellion, pp. 228-9; regarding black ganhadeiras in Salvador during that period, see Cecília Moreira, 'A mulher negra na Bahia no século XX', unpubl. MA thesis, Universidade Federal da Bahia (1994), ch. II.

40 APEBa, Abaixo-assinados, I850-55, maço 983; APEBa, Requerimentos, I857, n/c.

41 Reis, Slave Rebellion, pp. I66-7. 
and discipline the African street labour market in Salvador. The law divided the city into capatazias, which replaced the cantos, and created the position of capataz (foreman) to replace the capitão-do-canto. The goal of the capatazias was precisely to 'police the ganhadores', according to the legal document, no matter whether the ganhadores were slaves, freed or free; working on land or sea. The capataz was to receive 'a reasonable wage', which had to be paid by the ganhadores, in order to ensure their good behaviour and regard for law and order and prevent them from committing crimes against public order and private property. In other words, the ganhadores had to pay to be spied upon, and the capataz was not the only one to receive payment.

The law also obliged the ganhadores to register themselves, giving their names, and when enslaved, the names and addresses of their masters and the 'quality and kind of service to which they are accustomed'. That registration would be updated monthly, and anyone who neglected to do so would be punished with a fine of I०,000 réis, and twice that amount if the misdemeanour was repeated. That year, ı,,0०o réis could purchase at least is litres of manioc flour.

A year later, in April i 836, law I4 took statutory form. The regulations gave a detailed description of the new power structure of the former canto. At the top of the hierarchy stood the parish's justice of the peace, who was responsible for appointing an inspector for each capatazia that functioned in his jurisdiction. There had also existed 'block inspectors', who helped the justices of the peace to police the parish. In addition to those officials, specialised inspectors were instituted to police capatazia. These inspectors were required to be literate Brazilian citizens with impeccable backgrounds, resident in the parish where they served. They were responsible for registering the ganbadores and for watching over them, preventing the theft of transported goods and informing on any behaviour that might threaten public order.

The inspector was also responsible for appointing the capataz, whose duty was always to 'obey the Inspector's orders'. However, the capataz was still an African, albeit an African trusted by the whites and never a slave. It was his duty to ensure that the ganhadores carried out their work assiduously, identifying the absentees and investigating truancy. The inspector was to be immediately informed of any irregularities. The capataz, was also in charge of collecting the ganbadores' daily levy of 60 réis for those working ashore and 80 réis for those who worked at sea, from which two-thirds would go to the inspector and the remainder to the capataz.

The capatazias were required to have at least ten members, and those with fewer would be broken up among the nearest groups. This measure 
474 João José Reis

helped avoid dispersion, concentrating the ganbadores and improving vigilance over them. The culminating control mechanism was the obligation of each registered worker to wear a metal bracelet engraved with the capatazia's and his own registration numbers. The capatazes were to wear similar tags attached to a black leather thong ("tiracollo de coiro preto') about the neck. This would mark the difference between the ordinary ganbador and his capataz. ${ }^{42}$

The plan therefore involved an attack on the canto that destroyed its independence from within, subordinating it to the parish; in other words, to the territorial jurisdiction of white officialdom. Given the very nature of African work, the white rulers could not prevent Africans from circulating freely in the city; instead they sought to control their gathering places, enabling the government to play the role of overseer.

The law was not just displeasing to Africans. A long article published on 5 May 1836 in the Diário da Babia criticised it severely and in detail. According to the newspaper, the registration of ganhadores alone was discriminatory. The law, as a whole, contained 'incongruencies, irregularities and overly heavy precepts, and four nought...'. Not all the parishes were listed, which meant some ganhadores would have to be transferred to work in others under the watchful gaze of unknown inspectors. This also made it difficult for customers to gain access to registered ganhadores, when previously 'any person from his window, from a shop or in general from all parts called those who carried goods for one or more vintens, frequently without his being a true ganhador'. It also upset the lives of the slaveowners, whose household slaves were constantly stopped in the streets to verify whether they were working for hire or in their master's service. And what of those who were being lent out by slaveowners to their friends? And what about the capatazias whose members were exclusively slaves? How to appoint a freed capataz, to lead them?

Two features elicited further critical notice from the Diário: the obligatory use of metal tags and the manner in which the inspectors and capatazes were paid. The latter appalled the writer: 'Esta com effeito assusta!!' (That is truly astonishing!!). And he inquired:

What is wrong with a ganbador, whether slave, ingenuo (free), or freed, providing a common service, carrying heavy loads, tiring himself, weakening his health and often losing his life, but, nevertheless, extracting from his small daily profit three or four vintens merely to enrich the inspector... and the capataz?

He predicted 'great arbitrariness' on the part of those officials, who demanded to be paid whether or not a ganbador had found work. However,

42 Colleção de Leis e Resoluções da Assembléia Legislativa da Babia, I835-184I, vol. I (Salvador, I 862), pp. 22-7. 
the author knew that the ganbadores were no fools. He foresaw that they would certainly pass on the burden of payment to their customers, and with the increased price of transportation, 'the merchandise itself, which was sold to the Public for one price, will increase in cost'. In the end, the consumers themselves - the whites - would suffer, and thus the Diário avoided giving the impression of defending the Africans. However, it did not fail to come to their defence in particular. The commentary on the tags was full of irony:

If by the year I 835 we only saw a few prisoners wearing leg irons [to perform forced labour], from the year I 836 forward we shall see voluntary workers with chains about their wrists, and certainly any curious Foreigner coming to Bahia will not fail to note in his Memoirs the classificatory spirit that characterises us and our most decided love of badges: but should the irons be affixed or not ? $^{43}$

And if they were to be permanently attached, would the freedmen, for example, have to wear them to church, when visiting, or to parties? (Of course, the author was imagining odd situations in order better to ridicule the measure.) Worse, the Bahian authorities would be ridiculed by foreign travellers, when the white Bahians believed they were impressing them with supposedly European order and discipline in a predominantly black city. However, the newspaper raised a fundamental issue: wearing such a badge on their bodies would be an ignominious and humiliating means of controlling the Africans. The comparison with the gaols that chained prisoners doing forced labour is an excellent one. The ganbadores might be slaves, but apparently the gaol of slavery was not the worst fate in the sad city of Bahia. And if they were freed ganhadores their badges would suggest that slavery still haunted them. These significations were to emerge once again in 1857 .

Meanwhile, the justices of the peace attempted to enforce the new law. Ignoring its critics, the government used the pages of the Diário da Babia itself (27 May I 836) to clear up any doubts the justices of the peace might have when implementing the law. It explained, for example, that when there were no freedmen to appoint as capatazes, a slave could be named to that office, but only with his master's permission; the tags had to be paid for by the ganhadores or slaveowners; the ganhadores could circulate throughout the city and not merely within their capatazia's district. Other details were added that demonstrated the difficulty of executing these measures. For example, in February i 837 , a justice of the peace asked whether he should require household slaves to be registered when they had their master's permission to work on their own account after performing their domestic tasks and on Sundays. Several justices of the

43 The collection of the Diário de Babia of $18{ }_{3} 6$ is found in the Biblioteca Pública de Bahia in Salvador. Bold face in original. 
peace were in doubt about this, which demonstrates how widespread that practice had become. A decree issued by the president of the province ordered that no exceptions were to be made. ${ }^{44}$

While the president issued orders from the comfort of his palace, in the streets, a war of nerves was being waged. Justice Evaristo Ladislao da Silva, of the first district of Sé parish, declared that he was convinced that the measures were unenforceable, primarily because they established 'a tax that is not proportionate to the profits of those who must pay it'. ${ }^{45}$ In fact, the law on capatazias did not work. Its failure was primarily due to the fact that the ganbadores resisted it in every possible way. They refused to pay the inspectors' fee and to submit to inspection, gave fictitious names and addresses, jumped from one parish to another, confounding the registry, and some incited others to engage in a form of civil disobedience.

A capatazia inspector in the first district of Sé parish had already given up his post in early February I 837, and the justice of the peace could not find anyone who wanted to replace him. Evaristo Ladislao, the justice, informed the president that the ganhadores refused to pay the inspector or to subject themselves to review. As a result, he had decided to employ 'some little violence'. No matter how small that violence might have been (and what would the Africans have had to say about its extent?), no one offered their services for hire during the days that followed. The district's merchants were already complaining of the lack of labour for porterage. The justice himself experienced the lack in his own service. His colleague Felix da Graça Pereira Lisboa, of the second district, had advised the president that January that there were only thirteen sedan bearers there, a small number for the populous Sé parish. The rest had fled to parishes where the law had not yet been implemented. And it was difficult to find the 'evadidos' (evaders) because they had not given their true addresses and the correct names of their masters. And that was in January.

In March, inspector Joaquim Cesar d'Almeidal of the same district, was ready to surrender. In an official letter to his justice of the peace, he complained that the ganbadores had not paid the amounts due to him for three or four weeks. Many were leaving for Conceição da Praia, one of the parishes in which the regulation had not yet been enforced. And he added: 'It has reached the daring extent that some blacks come to this capatazia to take individuals from this place to that, thus subverting in that manner the ganbadores registered here.' Note the verb he utilised: 'subvert' (sublevar in the original). The official knew that he was confronted with a movement that, although peaceful, was apparently threatening. It did not present a greater threat because what was at stake was not so much the institution of slavery, but the behaviour of the slaveholding State.

\footnotetext{
44 APEBa, Juizes de paz, maço 2688.
} 
Unlike Justice Lisboa, Inspector Almeida knew who the masters in his capatazia were, and went to them to demand his payment and ask the whereabouts of their slaves. However, masters and slaves were not always on opposite sides in this conflict. The slave-owners not only refused to pay the inspector, but assured him that their slaves were free to decide where they were to work. And they told him this with 'rude and aggressive expressions', as the unfortunate Almeida complained to Justice Lisboa. ${ }^{46}$

Conceição da Praia parish, the waterfront area to which the Sé ganhadores were escaping, had become free territory. Early that same year (I 837), the justice of the peace of Pilar, a neighbouring parish, complained that he was unable to establish his maritime capatazias because boat owners no longer moored there. They had all gone to Praia. At Pilar, almost all the inspectors were resigning, which also indicates that the land capatazias were not doing well. The justice of Pilar asked the president to force the justice of Conceição to obey the law. Confusion appeared to have set in permanently. ${ }^{47}$

In due course, the authorities gave in. this was probably due, in part, to pressure from merchants hurt by the difficulty of arranging transportation, slaveowners feeling the lack of security for their hired-out slaves' activities, and many people lacking sedan chairs, as well as the justices of the peace themselves, who were worn out by the struggle to make the ganhadores obey them. That disobedience, however, was what actually overthrew the law. The victors, slaves and freedmen, reoccupied their territory, and what was to have been a capatazia went back to being a canto.

One of the features of the capatazia law that displeased the critic writing for the Diário da Babia in I 836 was the fact that the Provincial Legislature had usurped the City Council's right to regulate the ganhadores. In his view, the ganbador was a matter to be handled by the city government, and the provincial government should concentrate on more serious affairs. In fact, many city regulations controlled the minor street commerce to which the Africans, in this case mainly women, devoted themselves.

The city ordinances covered weights and measures, designated the sites where specific goods could be sold and forbade the placing of food stalls in heavily travelled areas. Vendors who disobeyed the law had their wares confiscated, and were obliged to pay heavy fines and go to gaol. The aldermen were constantly bombarded with complaints from residents and customers regarding lax inspectors and complaints from ganbadores and slaveowners in regard to overly strict inspectors. In I 839, for example, a letter published in the Correio Mercantil (22 April I 839), signed by the anonymous 'Enemy of Laxity', called for the removal of a small fish 
market in Preguiça Street to the place designated for such activities by the Council. The reader complained that 'the ganhadeiras, fish buyers and the said scoundrels leave so much rubbish in that area that it is impossible to pass through'. In addition to loud conversation, the stench and the obstruction of traffic, he complained of the colour of the people who gathered there: 'Oh Heavens, I have never seen anything so comparable with African Guinea!' And he insisted in making that comparison: 'Only there would one see such foulness, such blackness in one spot'. The citizen ('I am a Brazilian', he wrote) even used rhyme to associate blacks with refuse, ${ }^{48}$ which suggests that his complaint was merely a pretext for expressing racist sentiments.

Nevertheless, the inspectors were not as tolerant as the 'Enemy of Laxity' would have it appear. In July i 835 , for example, Inspector José Custódio Lobo wrote in an official document that he had arrested 'some black women... who were disturbing public transit with their wares'. And their vigilance did not relax with the passing of time. In the year of the strike, I 857 , fines were issued to the African slave Esperança for selling her wares in a forbidden place; and to a slave selling water who tied up his donkey at the door of a shop when he was unloading water for a household. These examples were selected at random among dozens of others. $^{49}$

If city regulations had become the chief instrument of controlling the labour market, the provincial government had not given up on taking a hand in the matter. The greatest representative of that policy, as Manuela Carneiro demonstrates, was Francisco Gonçalves Martins, the police chief who helped suppress the revolt of the Malês in 1835 . When he became president of the province in I 849, he continued to persecute Africans as if wishing to finish the job he had begun is years earlier. In i 850 , Africans had suffered a major setback when they were forbidden to work on the saveiros that unloaded the cargoes of ships anchored in the harbour. From that time on, boatmen were to be 'free persons, with the exception of Africans', ordered Martins. That measure was just one of the means used to make room for free citizens in the urban labour market. However, if it was logical to prevent slaves from working aboard saveiros, the extension of the prohibition to freed Africans was a clear ethnic persecution; and, given Martins's authority, political persecution as well. In ${ }^{8} 5_{3} 3$, there was said to have been a Nagô conspiracy that the British consul attributed to the pressure of unemployment caused by the former police chief's measures. Martins took advantage of the rumoured conspiracy to repress

48 Translator's note: the writer rhymes 'porcaria' (foulness or filth) with 'negraria' (blackness: a derogatory reference to a group or gathering of blacks).

49 AMS, Câmara. Corespondência de fiscais, I835, n/c; AMS. Requerimentos, I857, n/c. 
the Africans even further, imprisoning many, and once again to propose the mass expulsion of freedmen. That anti-African spirit, which had nothing to do with abolitionism, went unnoticed by Bahian abolitionist Luis Anselmo da Fonseca, an enthusiastic supporter of Martins's effort to promote free labour. ${ }^{50}$

Such measures were designed to force Africans to work on plantations as dependent labourers or make them return en masse to Africa. Political pressure and the economic hardships of the difficult i 850 , including the terrible cholera epidemic of 1855 , intensified the movement of freed slaves returning to Africa. In I 857 , dozens of announcements were published in Bahia newspapers in which Africans informed their friends and customers of their decision to leave the country. For example, on 2 I February, Salvador Ramos das Neves announced that he was leaving, "taking his family', which included his wife and five 'free children'. The shipping companies announced voyages to the West African coast. In February, the Independence sailed for Onim (now Lagos, Nigeria), a ship 'of the finest class and with excellent accommodations for passengers', as advertised by its co-signatories Gantois \& Marback. This same firm had played an active part in the illicit slave trade with Bahia from I83 I to i 850 . Now, it was making money by legally transporting freed Africans back to Africa. ${ }^{51}$

The strike of 1857

The law promulgated in 1857 was therefore part of a long-standing campaign to control labour in Salvador. However, this law was milder and simpler than that of 1835 . The only legacy of the previous law was the requirement of registration and the use of the identification tag. The new law contained nothing, for example, regarding the reorganisation of the cantos, perhaps because the same failure which met the 1835 law had been envisaged.

The work stoppage began well. Our main source of information on the course of the movement is the Jornal da Babia, which always published news of it on the first page. Regarding the beginning of the strike, it reported the following on 2 June:

Yesterday the city was empty of ganhadores and sedan bearers. One could not find anyone willing to carry any kind of object. Nothing left the customs house, unless it were a most portable object, or removed by the slaves of the interested party ...

50 Falla que recitou o Presidente da Provincia etc. (Salvador, I 85 I), pp. 33-4; Manuela C. da Cunha, Negros, estrangeiros: os escravos libertos e seu retorno à Africa (São Paulo, 1985), pp. 96-7; Verger, Flux et Reflux, pp. 537-8 (on the 1853 conspiracy); Luis Anselmo da Fonseca, A escravidão, o clero e o abolicionismo (Recife, I988; orig. I887), part 2, ch. 2.

51 Cunha, Negros, estrangeiros, pp. 62-100 (anti-African movement); Jornal da Babia (1 8 Feb I 8 57); Verger, Flux et Reflux, pp. 453-4, 537-8. 
The blacks have hidden themselves; and if the masters do not intervene, ordering them to obey the Law, this calamity will continue because, according to what we have heard, they are so disposed.

The newspaper states that the main reason for the stoppage was 'the execution of the measure obliging the ganhadores to wear a tag about their necks!' Thus, the tags were seen as the chief cause of the suspension of the transportation of people and merchandise in Salvador, primarily the paralysation of the port of a city devoted to foreign trade. The newspaper expressed the hope that the masters would intervene, making their slaves return to work. But that was not what happened.

On the very first day, the ganhadores gained an accidental but important ally. The Commercial Association, which represented the city's leading merchants, expressed a protest against the city ordinance to the president of the province, the future head of Pedro II's cabinet. João Lins Cansação de Sinimbú. They felt that the ganbadores' reason for striking was the 'tax', not the need for registration, a guarantor or a tag. The merchants were also unhappy about the money they would lose if their goods could not circulate.

The dependence of trade on the work of the ganbadores may never have been as clear as it became in 1857 . In I 85 I, James Wetherell wrote that the 'march of progress' had arrived in Bahia in the form of two trolley lines and several hired animal-drawn carts. Apart from these means of transportation, teams of mules were used to carry lime, rock, earth, and so on. But that was not enough. There had to be someone to load and unload the mules and wagons, which was the task of the ganbador. Furthermore, it was expensive to rent the carts, because, unlike the saveiros, their rental fees were not set by the government. In addition, the sector was a monopoly. The Bahia Almanak of 1857 listed in just two 'Renters of carriages, hansoms and carts'. The leader in business was the Austrian Rafael Ariani, the owner of carts for cargo and passengers, carriages for solemn occasions and hearses. The rents he charged were high, ranging from 40,000 to 50,000 réis for an ordinary cart and up to 70,000 réis for a wedding carriage drawn by four horses. As for hearses, the Jornal da Babia quoted one commentator as saying that 'in Bahia, dying is more expensive than living'. When complaints were made to Ariani, according to the same newspaper, he received them with 'his already proverbial... bad manners'. ${ }^{52}$

Depending on Ariani's wheels was not a good idea if one was a food stall owner, a wholesale trader or merely a sedan chair user. In fact, the

52 Wetherell, Brazil, p. 53 ; Camillo de L. Masson (Organisation.), Almanak administrativo, mercantil e industrial da Babia para o anno de I857 (Salvador, 1858), p. 365 ; Jornal da Babia (14 and 21 June 1857). 
use of carts, as well as the lack of merchandise in the city, would aggravate the increased prices caused by the strike. 'The penury grew', the Jornal da Bahia ( I June i 857 ) later wrote. Everyone wanted the ganbadores to return to their cantos. However, they were mistaken if they believed in the Commercial Association's theory that the only issue at stake was money.

Pressured by the merchants, the president of the province immediately ordered the Council to stop charging the registration fee and distribute the identification tag without charge. The president, like the merchants of the Association, was a believer in economic liberalism, which frequently set his group at odds with the City Council, which was more interventionist, regulating prices of vital goods. ${ }^{53}$ The heightening of the schism between the city's central powers (in fact, the City Council and the Presidential Palace stood in the same square) would be the first major political episode created by the movement.

The Council meeting held to discuss the president's orders divided the nine aldermen. Two of them, including the chairman, proposed that the registration fee be lowered to $\mathrm{I}, 000$ réis and that a guarantor for freedmen be dispensed with. That proposal was rejected. An alderman accused the president of the province of abolishing a legal tax because there could be no such thing as a 'permit without payment'. He accused the government of irresponsibility, because it had proved that 'it was not cognizant of its actions'. Reacting to the financial argument, another alderman referred to the need to follow procedures, defending the ordinance ' $[\mathrm{B}]$ ecause, like the Provincial Legislature, the President of the Province... cannot revoke, annul or substitute any Ordinance once it has been approved'. ${ }^{54}$

Ultimately the aldermen obeyed the president under protest. In a reply published in the press they recalled that he himself had approved the text of an ordinance, albeit provisionally, that was not only inspired but 'literally copied from the municipal laws of Rio de Janeiro'. In fact, in the imperial capital, the ganhadores had been obliged to wear tags since at least the early i 840 . With that exemplary model in mind said the aldermen, the Bahia ordinance was 'legal, just and feasible', including the fee charged for the metal tags. They merely omitted the detail that they were charging 3,000 réis for a tag that had cost 600 réis at the G. Colombo foundry. ${ }^{55}$

53 Eugene W. Ridings, 'The Bahian Commercial Association, 1840-1889’, unpubl. PhD Diss. University of Florida (1970), pp. i I6, I 20, I33.

54 AMS, Atas da Câmara, vol. 9.48, fos 274-5v. The following year (1 858 ), there was a food riot in Salvador, set against the backdrop of the political differences of the provincial and municipal governments. See Manoel Pinto de Aguiar, Abastecimento: crises, montins e intervenção (Rio de Janeiro, 1985), pp. 6I-73.

55 Luis Carlos Soares, 'Os escravos de ganho no Rio de Janeiro do século XIX', Revista Brasileira de História, vol. 8, no. I6 (I 988), pp. I I I-I 2 (Rio tags); Jornal da Babia (3 June I 857 ); AMS, Atas da Câmara, vol. 9.48, fo. 269. 
From the perspective of political argumentation, the best section of the aldermen's text was devoted to the ganhadores. Showing their experience in dealing with them, they described the movement as

a conspiracy or strike by African slaves and freedmen, not because the payment for the permit is burdensome - it is in fact insignificant for such a lucrative trade which pays no other taxes - but because they wish to dispense with any type of supervision. ${ }^{56}$

They warned the president that the strike set a very bad precedent for those who might wish to 'neutralise the Government's actions' in the future, and suggested that, rather than giving in, the authorities should attempt to neutralise the movement by using workers from the war arsenal, who were occupied in ship building, and the 'free Africans' confiscated as contraband and made wards of the State (also called 'the nation's Africans'). In the medium term, the Council believed that the best recourse was the creation of companies of freemen, which were already called for by a law decreed in i 855 .

However, the president paid no heed to the noise coming from the other side of the square. In his view, since the Council merely intended to discipline the ganhadores, the measure should merely police them and not tax them. Therefore, it was sufficient to require registration and make it obligatory 'for these individuals to wear a metal tag visibly, bearing their registration number'. Further, the Council had no right to create the tax without the Provincial Legislature's approval. The president echoed the criticism of the 1836 law, stating that if the tax were levied, the ganhadores would pass it on to their customers:

The Council knows that the imposition resulting from this permit falls on the consumers and not on the tax-payers, and therefore should consider that the relief intended by granting exemption from that tax is not destined for the slaves nor for the freed Africans, but for the consumers whose interests the authorities are duty-bound to serve, particularly when this is brought to their attention in the legal and peaceful manner in which the directors of the Commercial Association have done. ${ }^{57}$

Note that the president did not mention the slaveowners but rather the freedmen and slaves, recognising their relative freedom of action. He further argued that his policy was not intended to benefit the ganbadores, but the merchants who utilised their labour. However, if he was acting under pressure by the Commercial Association, the latter was being pressured by the strikers. The president ordered the aldermen to obey his command.

Therefore, on the second day of the strike, slaves and freedmen had already achieved a partial victory, defeating the 'fiscal' portion of the
56 Jornal da Babia (3 June I 857 ).
57 Ibid. 
ordinance. They continued their strike to eliminate the 'regulatory' portion. In the same issue that published news of the controversy between the City Council and the Presidency of the Province, the Jornal da Babia reported on the second day of the strike: 'the cantos were still deserted'. However, it observed that carts operated by freemen, as well as slaves acting as middlemen, had retrieved 'several packages' from customs. Many private parties were using carts, an expensive alternative as we have seen, and therefore strictly an emergency measure. Furthermore, all the available carts, free porters and household slaves could not handle the amount of merchandise that had to be transported.

The strike brought to light a debate on the ethnic segmentation of Salvador's labour market, which went beyond the mere replacement of slave labour with free labour. Freemen, even those of colour, considered it undignified to work side-by-side with African slaves and freedmen. According to the Jornal da Babia of is June:

$[\mathrm{M}]$ any free workers, who do not compete for that work because they do not want to perform it as the equals of African freedmen and slaves, would hasten to earn their bread [in that manner], which is far from plentiful, if they could do so fittingly, certain that they would not suffer the prejudices that they inherited and nurture.

Prejudice against Africans in general, and not merely African slaves, was rampant. It was not merely the rejection of colour or class; it was rejection based on ethnicity. It is no surprise that the Africans should also protect themselves with equally ethnic barriers. Naturally, prejudice increased to the extent that, when competing in the job market, freemen found the Africans to be admirably organised through the cantos. The cantos were therefore an instrument for protecting the market, a barrier preventing non-members from joining. Only Africans or those who submitted to them could join. At that time, African slaves and freedmen were better organised than free workers.

Therefore, the free workers, like the flour merchants described above, were constantly asking the government to protect them from the Africans. As a result of that protection, they began working as stevedores, loading and unloading the saveiros and ships anchored in the harbour. The law of I 850 , we should recall, forbade slaves and Africans in general from taking part in such activities. But in 1854 (therefore after the prohibition). 2 I.7 per cent of the 'sea workers' were slaves, which must have been partly due to their masters' pressure. During the crisis caused by the cholera epidemic in 1855 , that percentage doubled and remained stable in $1856 .{ }^{58}$ However, if stevedores were equally divided into slaves and freemen 35.2 per cent of the latter were white in 1856 - porterage beyond the

58 Mattoso, Babia: Salvador, pp. ${ }^{278-9}$; Cunha, Negros, estrangeiros, p. $9^{8 .}$ 
customs house was still dominated by predominantly African slaves and freedmen. That is why the strike had such an impact.

Reporting on the third day of the strike, the Jornal da Babia (4 June I 857 ) stated that transportation was still slow, 'despite the aid of some free workers and carts'. The strike appeared to be focusing exclusively on the use of metal tags: 'The rejection of these tags continues among the blacks. Yesterday, as on the previous days, the city was empty of black porters.' Like the journalist who criticised the tags in 1836, the newspaper perceived what was at stake. And if the press realised this it is because everyone did. More than rejecting the supervision of their work, the Africans rejected that specific form of control. The use of tags was viewed as humiliating. The Africans came from a world where the scarification of the body (Yoruba abaja), the use of specific necklaces, clothing, headdresses and hairstyles announced one's position in the social and ritual order. Both the ganbadores and aldermen knew that that tag embodied a decisive move. Their contemporaries fully understood that. According to the Jornal da Babia (6 June I 857 ), the Africans were struggling to 'free themselves of that shackle, which would so inhumanely equate them with miserable quadrupeds'.

There were other associations involved as well. The critic writing in I 836 compared the tag with a prisoner's shackle. A comment by Wetherell recalls an even more direct association: the collar welded around the neck of a habitual runaway slave. The Englishman wrote, 'This badge is considered a great disgrace, for when out their acquaintances jeer at them ${ }^{59}$ The fact is that iron clasped about the body was humiliating, and made the condition of slavery, of the body as chattel, even more burdensome. If the ring was used to punish the 'sin' of rebellion, the tag seemed designed to punish the ganhadores for the 'sin' of African ancestry.

On the third day of the strike, the reporter for the Jornal da Babia (4 June I 857 ) wandered the city alert: 'We have heard that shortly the blacks will be walking the streets as before, without tags or registration'. However, on that third day of the movement, the first defections began at the weakest link in the ganhador community: the slaves. Their masters were pressuring them to work (they had hastened to the Council House to register them, obtain their tags free of charge and get their slaves back to work as soon as possible). The Africans faced the difficult circumstance of acting politically in a labour market that was divided among freedmen and slaves. If the former were obliged to obey their leaders, clearly the capitãesdo-canto, the latter owed their obedience both to them and their masters. The slaves faced greater risks. If they disobeyed their masters, they could be punished, see their share of their wages reduced or even taken away,

59 Wetherell, Brazil, p. 70 (emphasis in the original). 
and possibly forfeit their chances of manumission, which depended as much on their master's goodwill as it did on their ability to purchase their freedom. Once the tax had been eliminated, the slave-owners saw no reason to resist registration. In fact, as of 4 June, when they realised that they no longer had to pay the fee, they hurried to register their slaves. Before that date, just three registrations were lodged in the Council archives, compared to 40 registrations made on the 4 th. ${ }^{60}$

Despite these difficulties, the strikers reacted using the tactics of modern-day picketers:

Some masters have registered their slaves, who go out into the streets with the said tag, but they are soon obliged to tear them off, not only because their comrades mistreat them and oblige them to do so but also because urchins and black women form rings around them, driving them to despair with scornful remarks and sarcasm.

The following day, the newspaper announced that the slaves wearing tags had been stoned by their comrades. Forced to remove them, they returned home because they could not work without being arrested by the Council's inspectors. ${ }^{61}$ One of these incidents resulted in a petition to the Council by Eufemia Maria das Dores Rocha:

$[\mathrm{H}]$ aving registered in this Office on the first of June her slaves, who work for hire with the numbers 99 and 100 , being that no. Ioo, by the name of Antonio, of the Ussá nation, returning home after the 'Hail Mary' [6:00 p.m.], a group of African urchins from Baixa de Sapateiros tore the tag which said slave bore about his neck, beating him...

The mistress of the Hausa slave (note his origin) requested that the money she had paid for the lost tag be returned. The Council acceded to her request, officially noting that the incident 'denotes the lack of police action' ${ }^{62}$

However, the police could not control the entire city. This was partly due to the fact that the ganhadores were not the only ones to defend their movement: the African community, including women and children, openly supported them. As we have seen, women controlled a good share of the street commerce in Salvador. Ganbadores and ganhadeiras jointly controlled the streets. Although they did not take part in the cantos, which were a male institution, the women formed part of the broader network of urban African workers. Possibly they did more to support the movement than simply discourage desertions. As food sellers, it is probable that they sold food on credit to the ganhadores, who had spent days without making a penny.

60 AMS, Atestados de conduta e matrícula de escravos, $1857, \mathrm{n} / \mathrm{c}$.

61 Jornal da Babia (4 and 5 June I 857 ).

${ }_{62}$ AMS, Atas da Câmara, vol. 9.48, fo. 283. 
Accompanying their mothers when they worked, or simply running loose in the streets, children of colour were also permanent figures in the nineteenth-century public setting. These 'urchins' (moleques) as black children were called, frequented travellers' diaries, police reports and even political chronicles. During the anti-Portuguese mutinies and other rebellions that took place in the 1820 s and I 830 , they played an important part as sharp-shooting rock throwers. ${ }^{63}$ On this occasion they joined with the black women in a form of charivari, to torment the poor slaves acting as unwilling scabs. As punishment for betraying the canto, those slaves were placed within the circle of community regulations, and it was not samba-in-the-round, although there may have been no lack of handclapping and humiliating songs.

The fourth and fifth days of the strike went by uneventfully, except for the occasional incident between ganhadores and the few slaves who dared to appear in public wearing the tag. The press, however, began to send out alarm signals. On 5 June, the Jornal da Babia announced, 'This unexpected resistance, which for three days was nothing but an ordinary novelty, is beginning to become a crisis'. In fact, Bahians must have been losing sleep in a city shut down by Africans - some of whom might have been veterans of slave rebellions - and where there was already talk of abolitionism in societies organised by young idealists, white and mulatto students at the School of Medicine.

In a lengthy review of the strike published on Friday, 5 June, the Jornal da Babia called the movement a 'dangerous crisis, a revolution', the 'revolution of ganhadores'; these were said to be 'new revolutionaries' who had 'understood that they had to impose their interests'. Despite the still-uncertain semantics of the word 'revolution' in Bahia at that time there is no doubt that the newspaper intended it to mean a profound break with law and order. As the voice of the opposition, it sought to demonstrate that the president of the province was responsible for the 'calamity' of the strike. It even cited aldermen as charging that, under him, the province was being 'governed by Africans', setting those words in bold-face type. The president, continued the writer, had shown weakness (or 'generous complacency') in the handling of the striking ganhadores, because he had recognised the legality of the ordinance before revoking it, thereby undermining the City Council's authority. A similar presidential measure, recalled the newspaper, had caused the 'cemiterada' (Cemetery Rebellion) of i 836, when a mob destroyed Campo Santo cemetery, unopposed by the police, to protest against a law forbidding burial inside churches; and the Sabinada of I 837, a Federalist revolt that

63 Regarding the 'urchins' of nineteenth-century Salvador, see Walter Fraga Filho, Mendigos, moleques e vadios na Babia do século XIX (São Paulo, 1996). 
captured Salvador for four months, during which period the president at that time was accused of failing to take decisive action against the conspirators. ${ }^{64}$ The African work stoppage was a 'revolution' with disturbing implications: 'What will the outcome be?' asked the newspaper.

The president, however, was unconcerned. That Friday, he travelled to his home province of Alagoas aboard the steamship Magé. He was 'burning good coal at the expense of the State', taunted the Jornal da Babia (6 June I 857 ). And it went on to ask: 'but what would His Excellency do if on his way he met with black ganbadores with their tags clenched between their teeth?' If the president had such a black nightmare at sea, we have no way of knowing. The fact is that the Bahians ended the week with a white man's nightmare: travelling on foot, taking letters to the post office, perhaps even lacking drinking water in their homes. How good it was to have Africans to provide all these services! In fact, in a good-humoured tone, a correspondent for the Rio de Janeiro newspaper Correio Mercantil (24 June I 857 ) wrote from Salvador on 4 June that the African strike had obliged 'respectable citizens to carry their own packages, which is more than just, because it is not in the least difficult for us to carry our own burdens when we are not physically disabled; the problem may be lack of dexterity, but that can be learned with practice' ${ }^{65}$

However, on Monday, 8 June, when the strike had lasted a full week, the first sedan bearers began to appear. The neighbouring cantos of Teatro Plaza (now Castro Alves plaza) and Baixo de São Bento Street (now Carlos Gomes) were filled with ganbadores. There was just one thing: none was wearing an identification tag. The following day, according to the Jornal da Babia (Io June I 857), the sedan-chair cantos were almost all 'full of bearers', and many ganhadores were already carrying loads, including wares from the customs house. None of them wore a tag. However, there were still not enough workers to bring the circulation of merchandise back to normal. Part of the work was still being done by free wagon drivers.

There is an explanation for the appearance of the ganbadores. That Tuesday, 9 June, the City Council - 'wishing to give unequivocal proof of their desire to promote... all that is good for the city's residents' - had revoked the March ordinance and replaced it with another. The decision was not unanimous. One alderman voted against it. Another withdrew in protest. While the Council was still in session, the new ordinance was taken to the presidential palace on the other side of the street and

${ }^{64}$ Regarding these two movements, see Paulo César de Souza, A Sabinada: a revolta separatista da Babia (1837) (São Paulo, I987) and João José Reis, A morte é uma festa: ritos fúnebres e revolta popular no Brasil do século XIX (São Paulo, I99I).

${ }^{65}$ Correio Mercantil, from the collection of the Biblioteca Nacional, Rio de Janeiro. 
promptly returned with the approval of the acting president, Vice President Manoel Messias de Leão. The city ordinance was published in the press the following day, the eve of Corpus Christi, which gave the strikers another day to decide how to proceed. ${ }^{66}$

The aldermen had abolished the tax, but they still required the tag. They also continued to require that the freedmen present a guarantor. However, there was one difference. The original ordinance read: 'present a guarantor who will take responsibility for [said freedman] in order to obtain the permit and the tag'. The new ordinance stated: 'present a certificate of guarantee from the official of the district in which they reside, and in the absence of this, from a notoriously respectable person'. This may not appear to have been a major change, but in fact it was. In the first case, a freeman had to take responsibility for the freedman's future behaviour, just as a master assumed responsibility for a slave. That meant creating a dependent relationship that may have been intolerable to the freedman. Furthermore, it would probably have been difficult to find someone who would risk undertaking such a commitment. The new ordinance merely required a certificate attesting to the freedman's good prior behaviour, issued by a police officer - generally the block inspector or justice of the peace - or a 'respectable' citizen.

In fact, certifications of the freedmen's good conduct were issued by former masters, friends of former masters, shopkeepers who were the ganhadores' customers, as well as inspectors and justices of the peace. Manoelino dos Santos guaranteed that Jacob Ojé (note the African surname, rare in a seigniorial document), a slave freed by him a short time before, 'has always demonstrated good behaviour both as my slave and now as a freedman...'. Olimpio Fiúza Moniz Barreto did not risk giving an opinion on the present behaviour of his former Nagô slave Luiz, but attested that 'while he was in my service, for over 20 years, his conduct was always irreproachable'. Cipriano Rigaud wrote in favour of Antônio João de Bastos, a ganhador at the Trapiche das Grades de Ferro canto, stating that 'he earns his living carrying any kind of object for the commerce of this city'. The guarantor had been a friend of João de Bastos, the ganhador's deceased former master. Paternalism went beyond the bounds of the seigniorial family to include close friends. It was as a 'close friend' of the last master of ganhador Aleixo Sanches, a sedan bearer at the São Bento hill canto, that Rigaud declared that the freedman was a 'fully capable black, to which other persons who have known him for many years, as I have, can also attest'. A good credit history enabled Marcellino and Balthazar to obtain the backing of merchant M. J. Magalhaes, who

66 Jornal da Babia (ı June I 8 57); AMS, Atas da Câmara, vol. 9.48, fo. 275v; AMS, Ofícios recebidos, $1857, \mathrm{n} / \mathrm{c}$. 
wrote: 'they enjoy credit at the trading establishments for which they used to work as porters ... ${ }^{67}$ In these cases, the freedmen either made use of dependent relationships with their former masters and people in their social circles, or utilised new relationships formed with their customers. ${ }^{68}$

Nevertheless, most freedmen obtained their certificates from block inspectors and justices of the peace, which suggests that they chose to escape the cycle of dependence on their former masters and enter into a direct relationship with political authorities without intermediaries. In such cases, they personally had the certificate of guarantee drafted by a legal representative and submitted it to the official for his signature. Many ganbadores from the Vitória district, for example, paid Firmino da Costa Menezes to write their petitions. Menezes must have set up his office in the street to meet the demand. Interestingly, the letters contain wording that clearly expressed the ganhadores' grievance: 'It happens that the City Council has created an Ordinance that obliges the ganhadores to wear a tag that sets them apart from workers plying other trades, and that this is conceded to those who present a certificate guaranteeing their good behaviour... ${ }^{69}$ In a way, these words denounce the discrimination suffered by the Africans, and it is possible that the idea of introducing them did not originate from the scribe and attorney Menezes. The Africans were fully aware that they were being socially devalued, relegated to the status of pariahs.

On the I 2 th, a Friday, many ganhadores appeared in the streets wearing their tags. A record number of slaves were registered on that date. Most of the certificates of guarantee for freedman available for consultation were also submitted on that date. However, not all ganhadores were seen wearing the tags. Some probably failed to do so out of resistance, and others because the Council ran out of tags, as it had not had a sufficient amount made. However, the Jornal da Babia (I 3 June I857), without neglecting to criticise the aldermen's inefficiency, announced that 'things are beginning to straighten out'. The strike was virtually over. In the days that followed, Salvador's transportation services would return to normal.

The ganbadores had gone as far as they could. After holding out for more than a week without pay, they had probably reached the limits of their resistance. On the basis of the statements of daily income given in 1849 ,

67 AMS, Atestados de conduta e matriculas de escravos, $1857, \mathrm{n} / \mathrm{c}$.

${ }^{68}$ In Brazil, former masters were considered the patrons (patronos) of their freed slaves, and until i 87r they could attempt to revoke manumission papers in the courts, either because they were conditional or because they considered themselves the victims of the freedman's misbehaviour. Thus, the freedman's dependence on his patrons was sanctioned by law. See Manuela Carneiro da Cunha, Antropologia do Brasil: mito, história, etnicidade (São Paulo, I986), pp. I 26-44, and the revisionist work by Keila Grinberg, Liberata: a lei da ambigüidade (Rio de Janeiro, 1994). $\quad{ }^{69}$ Ibid. 
without considering inflation between that year and i 857 , we can calculate that the average ganhador had lost from 7,000 to 10,000 réis. In the year of the strike, I0,000 réis was enough to purchase 30 kilos of meat.

The movement had been partly successful. It did away with the registration fee and modified the terms of the 'guarantee'. Managing to paralyse an important sector of urban labour for over a week was a major feat in and of itself. That it was possible at all must be attributed to the fact that the ganhadores were not a disorganised mass that lacked an understanding of its own interests. Their contemporaries knew this. Giving an overview of the strike, the Jornal da Babia (Is June i 857 ) admitted that the president had opposed the ordinance 'due to the Africans' resistance'. And that resistance had been effective because 'the Africans [acted] with a single voice, driven by a single will...'

How was that possible? Unfortunately, we lack the testimony of the ganhadores themselves. The ganhadores simply communicated their feelings throughout the city by word of mouth. Apart from the strike itself, all we know regarding the African camp during those few days is limited to the attacks on strike-breakers. Furthermore, because the authorities were taken by surprise by 'a new sort of revolution', in addition to being divided, they did not use force to combat it. There were no legal grounds for repressing the strike, as there was no specific legislation dealing with strikes, a form of movement that, I repeat, was a novelty at that time. Thus, there was no police investigation, with arrests and interrogations, which would furnish the type of documents that might provide an insight (however distorted) into the movement's internal workings. We must content ourselves with reading between the lines.

The cantos certainly played a fundamental role in the organisation of the strike. In order for everyone to stop working in an orderly fashion with 'a single voice' it was necessary to debate, agree upon, decide for and mobilise the strike to an extent that was only made possible by an existing organisation. That leads me to believe that the cantos were not small, isolated 'kingdoms' but a form of federation, which is confirmed by the presence of delegations from various cantos when the capitães-do-canto took office. As in 1835 , it is clear that in 1857 they had formed not only economic and social networks but political ones as well. Again, the fabric of those networks was 'the nation'. But which?

As we have seen in data provided by the 1849 survey, the Nagôs predominated among the freedmen and slaves working as ganbadores. Evidence from i 857 confirms this. There is little information on the freedmen: in the 29 registrations or guarantees that reveal something about their origins. I 7 state merely that they are 'Africans'; I I are Nagôs and just one is Jeje. We have more information on the slaves. Out of the 
477 registrations I have found, 63 contain no reference to the slaves' nationalities; another I 73 list them merely as 'Africans', and I86 as Nagôs. The other ganhadores included I 2 Angolans, 9 Hausas, 7 Tapas (Nupe), 6 Jejes and another I 2 Africans from other nations. There were only nine Brazilian slaves, all of them Crioulos. Considering only the $24 \mathrm{I}$ ganhadores whose specific nations can be identified, 77 per cent of that group were Nagô. This does not mean that the strike was organised by the Nagôs alone. However, their superior numbers certainly made it easier to mobilise the strike in 1857 . And once they had decided to strike, who would dare to oppose them? Let us recall that the Hausa slave Antonio, who ventured into the streets wearing a tag during the strike, was sent home soundly thrashed and tagless. Ethnic identity, which played an important role in the violent slave revolts organised before i 835 , did so once again, now that the Nagôs were adopting the peaceful tactic of collective resistance.

There was one difference, however: due to their numbers, 'Nagô' had become virtually synonymous with 'African'. In i 835 , nearly 29 per cent of African slaves were Nagô. In I 857 , they numbered 77 per cent. That enormous Nagô umbrella must have sheltered many Africans from minority nations whose numbers may not have been sufficient to form their own canto, for example. Therefore, they became 'naturalised' Nagôs. This does not mean that they had abandoned their own ethnicity. However, when entering Nagô social networks, they had to give up part of their former identity. During the second half of the nineteenth century, the smaller ethnic groups were rapidly shrinking, with the exception of the numerous Nagôs. They would take up so much ethnic room that, from the Africans' perspective, 'the Other' would be less and less other Africans and more and more the Bahian. Whites, Crioulos and mulattos also began to see fewer differences among the Africans and perceive the Nagôs as typical of their kind. Thus, a form of Pan-Africanisation of ethnic identity can be seen in Bahia in the second half of the nineteenth century. Therefore, unlike the 1835 revolt, the 1857 movement was not seen by its contemporaries as Nagô but as 'African'. Let us recall the City Council's description of the strike: 'a conspiracy or strike by African slaves and freedmen...' The Africans were predominantly Nagôs. ${ }^{70}$

The movement had its limitations, which we could term organisational. Although, according to the Jornal da Babia (5 June i 857 ), the majority of ganhadores consisted of freed Africans, the number of slaves was also

70 In modern-day Bahia and other regions of Brazil, the convergence between 'African' and 'Nagô', the latter being a symbol of 'African purity', is found at several levels of popular culture, particularly among the Afro-Brazilian religions. See Beatriz Góis Dantas, Vovó nagô e papai branco: usos e abuses da África no Brasil (Rio de Janeiro, 1988). 
significant. If the freedmen's occupations were similar to those of slaves, the condition of freedom placed them on a different level of the social and power hierarchy. As we have seen, slaves were the first to defect, obeying their masters' orders. If their ethnicity, occupations and the racial prejudice they suffered served to unite them with their freed comrades, slavery divided them. The Santana survey of i 849 gives a convincing illustration of that situation: 78 slaves were owned by African freedmen, and 47 belonged to masters of their own ethnic group. The movement might have possibly gone further if such differences had not been present. At the same time, having gone as far as it did, or even been staged at all, it attests more to alliance than to schism.

The 1857 movement elicits broader issues. The strike as a means of struggle was not unknown to slaves in the Americas. ${ }^{71}$ However, it became the chief method of struggle peculiar to the modern urban worker, primarily factory workers. As Charles Tilly observes, the strike was reinvented many times in history, but only when the urban-industrial system began to predominate in the nineteenth century did it become a permanent part of the repertoire of collective action by the working class. Before then, the poor had learned to act as a class by rebelling against high prices and the lack of food (food riots), against laws that went against traditional customs, against the imposition of taxes and so forth. Such reactive movements involving defensive mobilisation to prevent morally unacceptable changes were on the wane and virtually extinct in Europe, having been primarily replaced by the strike, a generally proactive movement to demand better pay and working conditions. ${ }^{72}$ That was the European model. When compared with Bahia in I 857 , what we have seen here was a hybrid movement. The strike was a reaction against the Government's attempt to revoke the Africans' 'established rights and routines' (Tilly), including the imposition of a tax of 5,000 réis and the use of a tag hung from the neck. They did not rebel against it; rather, they went on strike, a movement common to the 'modern' worker. It was a tax strike. The ganhadores were collectively organised on the basis of ethnicity in the process of 'informal' urban labour In the dynamics of the 1857 movement, there was a complex relationship between class and ethnicity. The Africans were foreign urban workers, foreigners of the same

71 Regarding rural slave strikes, see, for example, Michael Craton, Testing the Chains: Resistance to Slavery in the British West Indies (Ithaca, 1982), pp. $225,253,280,291,300$; Mullin, Africa in America, pp. 208-9, 254, 258 (the greatest Jamaican rebellion of I 83 I was originally planned as a general strike to begin on the first day of 1832); Carolyn Fick, The Making of Haiti: The Saint Domingue Revolution from Below (Knoxville, 1992), p. 98; Robert Conrad, The Destruction of Brazilian Slavery (Berkeley, 1972), pp. 264-5, mentions slave strikes in Brazil in 1887 .

72 Charles Tilly, From Mobilization to Revolution, (Reading, I978), ch. 5 and p. 146. 
nationality, aware of their importance to the running of the city, masters of the service market which the government was vainly attempting to control. This explains the style of resistance they chose, and its relative effectiveness.

When the strike ended, collective resistance was replaced by individual action. On 29 September I857, Ivo, an African slave, was arrested because, according to city inspector José Pinto Ferreira, ' $[\mathrm{H}] \mathrm{e}$ not only failed to wear the tag but also did not want another to wear it'. ${ }^{73}$ Ten days later, Ludgero dos Santos Piedade, another inspector, informed the chief of police that he had arrested

[A]n African black who, setting down the sedan chair that he was carrying and entering a shop, was followed by me because I heard him say that he had earned a great deal of money, and I asked him for his tag, to which he responded that he had a tag but could not show it to me, and when I ordered him to show it to me as an Inspector of the City Council with a mandate to that end, it was in vain, which moved said black to insult me with words, to the point that he meant to strike me and if he did not, it was because I was accompanied by another officer who arrested him, and even so, the prisoner struggled greatly ... and swore all the way that when he found me again he would teach me a lesson, that he knew me, that his master was not poor... ${ }^{74}$

Apparently, the inspector did not like to see Africans making money, which led to his decision to persecute him. African slaves frequently used their master's good name to defend themselves against arrogant policemen, as though by being the slave of a powerful man they shared his power. However, it was not only the slaves of wealthy men who dared to resist. Similar incidents became increasingly frequent. The tag would not mark the bodies of the ganbadores for long. The name of the African arrested by Ludgero was Augusto, of the Nagô nation.

73 APEBa, Polícia, maço 632 I. $\quad 74$ APEBa, Polícia, maço 648 I. 